Bangladesh J. Plant Taxon. 20(1): 67-76, 2013 (June)

(C) 2013 Bangladesh Association of Plant Taxonomists

\title{
ETHNOBOTANICAL STUDIES OF WILD HERBS OF CENTRAL PUNJAB, PAKISTAN
}

\author{
Arifa Zereen ${ }^{1}$, ZaheEr-Ud-Din Khan And Andleeb Anwar Sardar \\ Department of Botany, GC University, Lahore, Pakistan
}

Keywords: Ethnobotany; Wild herb; Herbal Medicines; Pakistan.

\begin{abstract}
The current research work was designed to file the indigenous knowledge on the flora of eight districts of Central Punjab, viz., Faisalabad, Pakpattan, Lahore, Nankana Sahib, Narowal, Sahiwal, Sialkot and Vehari. Frequent field trips were made during 2006-2008 to record ethnobotanical data by interviewing people of various age groups, mostly ranging between 30 to 70 years, including medicinal healers (herbalists/hakims). The total number of species recorded was 102 that belonged to 90 genera and 38 families and were being used by local people of respective districts for various purposes e.g. medicine, fuel, fodder, vegetables, fruits and for making mats and baskets.
\end{abstract}

\section{Introduction}

Different ethnic groups of the world possess empirical knowledge about the utilization of local flora of that area on which they are immediately and intimately dependent. Plants and plant products continue to play a fundamental part in the material culture of many of the world's indigenous communities. However, with the increased contact with industrialized world and through the erosion of their natural source base, the indigenous knowledge is gradually vanishing.

Pakistan comprising nine major ecological zones is bestowed with a unique biodiversity. About 6,000 species of wild plants are found in the country, out of which almost 400 - 600 species are considered to be of medicinal importance (Hamayun et al., 2005). In Pakistan, medicinal plants are primarily used by Tibbi Dawakhanas (medical centers of indigenous physicians known as Hakims). The study of traditional uses of plants in Pakistan has been increasing during the last few years (Hamid et al., 1996). Aboriginal remedies which are believed to be inexpensive, safe and more effective are gaining recognition among the people of both countryside and city areas. Knowledge gained from tribal groups about indigenous long-established medicine has played a very important role in the discovery of new products from plants as chemotherapeutic agents (Katewa et al., 2004). People living in villages and tribal localities are using native plants for medicinal and various other purposes from time immemorial as this knowledge is based on experience and reaches them through generations (Shinwari and Khan, 1998). In an ethnobotanical study in Bangladesh the use of plants for medicinal purposes among four indigenous communities of Bandarban was recorded (Mohiuddin et al., 2012). In another study Patel and Patel (2012), showed the ethnogynaecological uses of plants from Gujarat, India. In this regard 16 plant species belonging to13 families were documented. Rawat and Kharwal (2010) provided ethnobotanical information on Sapium insigne, a conserved plant of Shivalik Hills, India. The plant was used by locals for fish poisoning. Pragada and Rao (2012) highlighted the ethnoveterinary uses of plants to treat common diseases in cattle and pet animals in tribal belts of Andhra Pradesh, India. In a study conducted by Sardar and Khan (2009), the indigenous knowledge of local people of Tehsil Shakargarh, District Narowal, Pakistan about medicinal and conventional uses of plants was reported.

${ }^{1}$ Corresponding author. Email: arifazereen@yahoo.com 
Punjab is ranked as Pakistan's second largest province after Baluchistan with an area of $205,344 \mathrm{~km}^{2}$ and is located between latitudes $27.42^{\circ}$ and $34.02^{\circ} \mathrm{N}$ and longitudes $69.81^{\circ}$ and $75.23^{\circ} \mathrm{E}$ at the northwestern edge of the geological Indian plate in South Asia. The present study has been carried out to collect, identify and document the ethnobotanical plants used by the indigenous people of Central Punjab.

\section{Materials and Methods}

In order to collect the data 32 field trips were made during the year 2006-2008. The local names, traditional and medicinal uses of the herbs were recorded by interviewing the local persons of different age groups mostly between 30 to 70 years, including herbal practitioners. The collected plant specimens were pressed and identified with the help of Nasir and Ali (1970-1989), Ali and Nasir (1990-1992), Nasir and Rubina (1995) and Ali \& Qaisar (1992-2007). A questionnaire was developed for documenting ethnobotanical knowledge. The collected information was also crosschecked with the available literature.

\section{Results and Discussion}

A total of 102 species under 90 genera and 38 families were recoded which were being used by local inhabitants for various purposes such as fodder, furniture, fuel, medicine, edible fruits and vegetables (Table 1). Most of the species are reported to have multipurpose use by the inhabitants of the respective areas. They use them as medicinal plants (74 species), fodder (50 species), vegetables ( 9 species), wild fruits ( 2 species), reclamation of saline soils (1 species), multifarious use (8 species), herbal veterinary medicines (3 species), fuel wood (2 species), crop weeds (2 species), poisonous (1 species), religious value (1 species), condiments (1), narcotic (4) and cosmetic (1) etc. Majority of the herbs present in the study area have medicinal use and in order to treat various diseases a variety of plant parts are used. The local people use plants for a number of ailments like bronchial disease (19 species), blood purifier (9 species), fever (19 species), hepatic problems (5 species), arthritis (5 species), sexual diseases (11 species), digestive disorders (43 species), general tonic (6 species), diabetes (4 species), urinary diseases (4 species), eye diseases (7 species), ear problems (3 species), hair fall (2 species), toothache (4 species), skin problems (18 species), piles (7 species), wound healing (6 species), jaundice (4 species) and cardiac problems (3 species).

Population of the Punjab Province estimated to be 70 million is comprised of about half the total population of Pakistan (Punjab World Gazetter in 2009). Central Punjab with a good number of renowned cities is the hub of industrial, agricultural, educational and business activities. In the process of urbanization construction activity consisting of multistoried buildings, industrial units and roads in the area is therefore more compared to the other parts. These developments have greatly influenced the plant biodiversity (Cubizolle et al., 2003). Central Punjab is quite rich in plants of economical importance, with record of 102 species of herbs confirming the fact. Local people have depended upon indigenous plants since long for their means of living like food, medicine, shelter, trade besides the needs of fuel and animal feed etc. Most of the herbs because of their great medicinal value have remained under heavy anthropogenic pressure in the form of cutting, harvesting and grazing. With the support of fertile land and a vast irrigation system majority of the land owners in Central Punjab use pesticides and herbicides to obtain higher yields, which create pollution and destroy vegetation in the adjoining areas. Pollution of gasoline containing heavy metals also causes damage to plants on road verges (Gracia-Miragaya et al., 1981; Gjessing et al., 1984). In all this situation people's awareness about the sustainable use and conservation of these species is primarily essential to control indiscriminate cutting and damaging process before many of these become non-existent. 


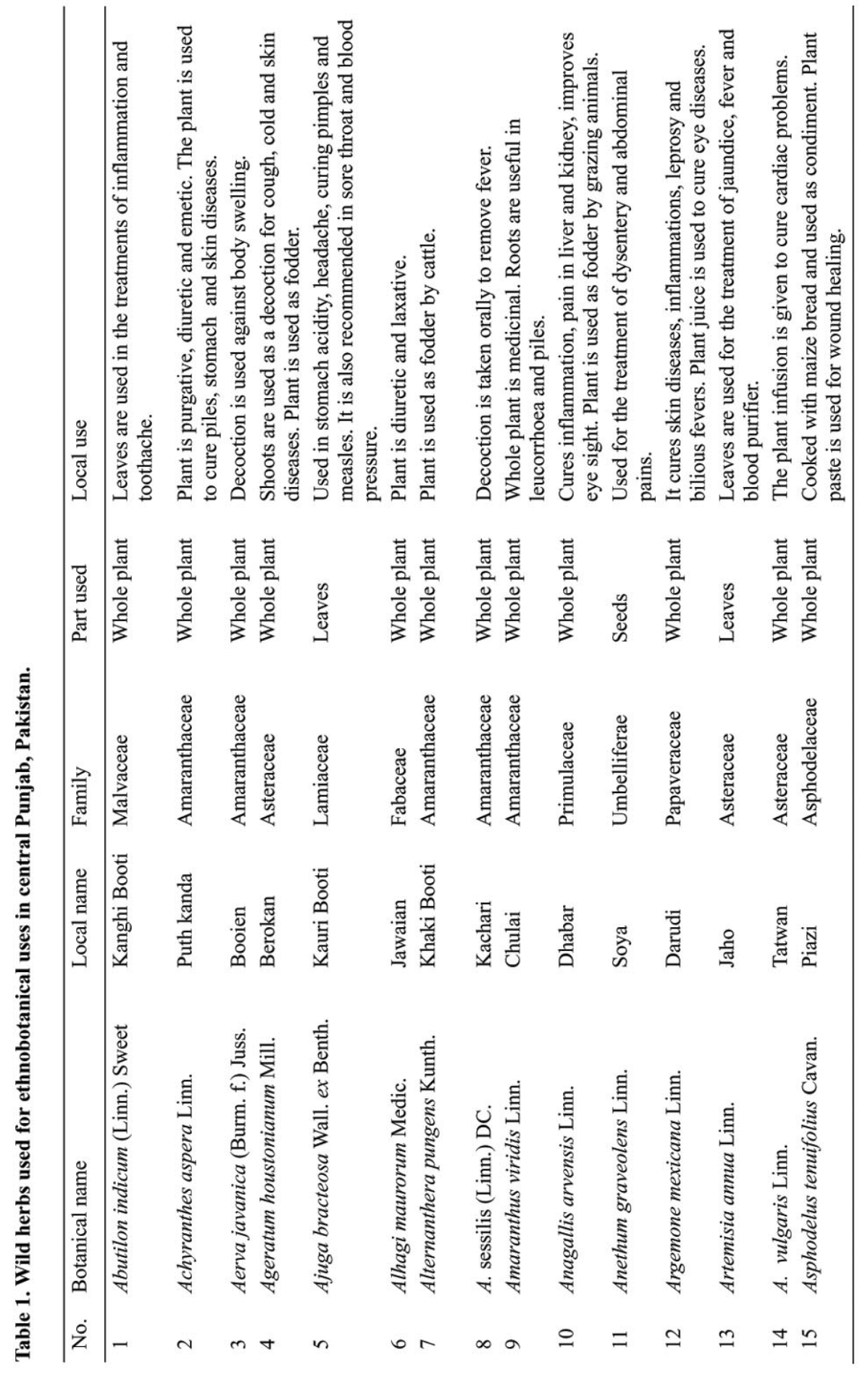




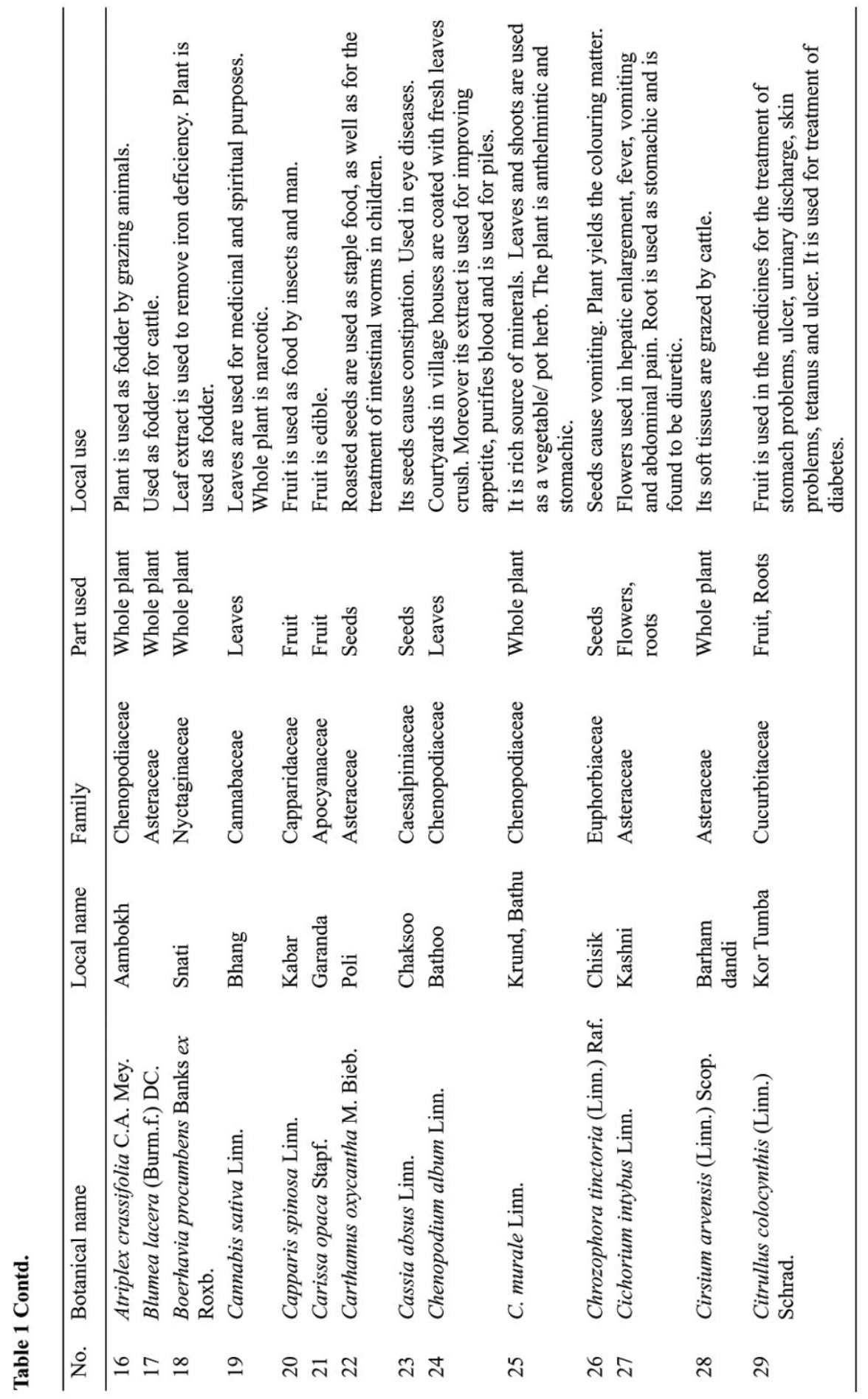




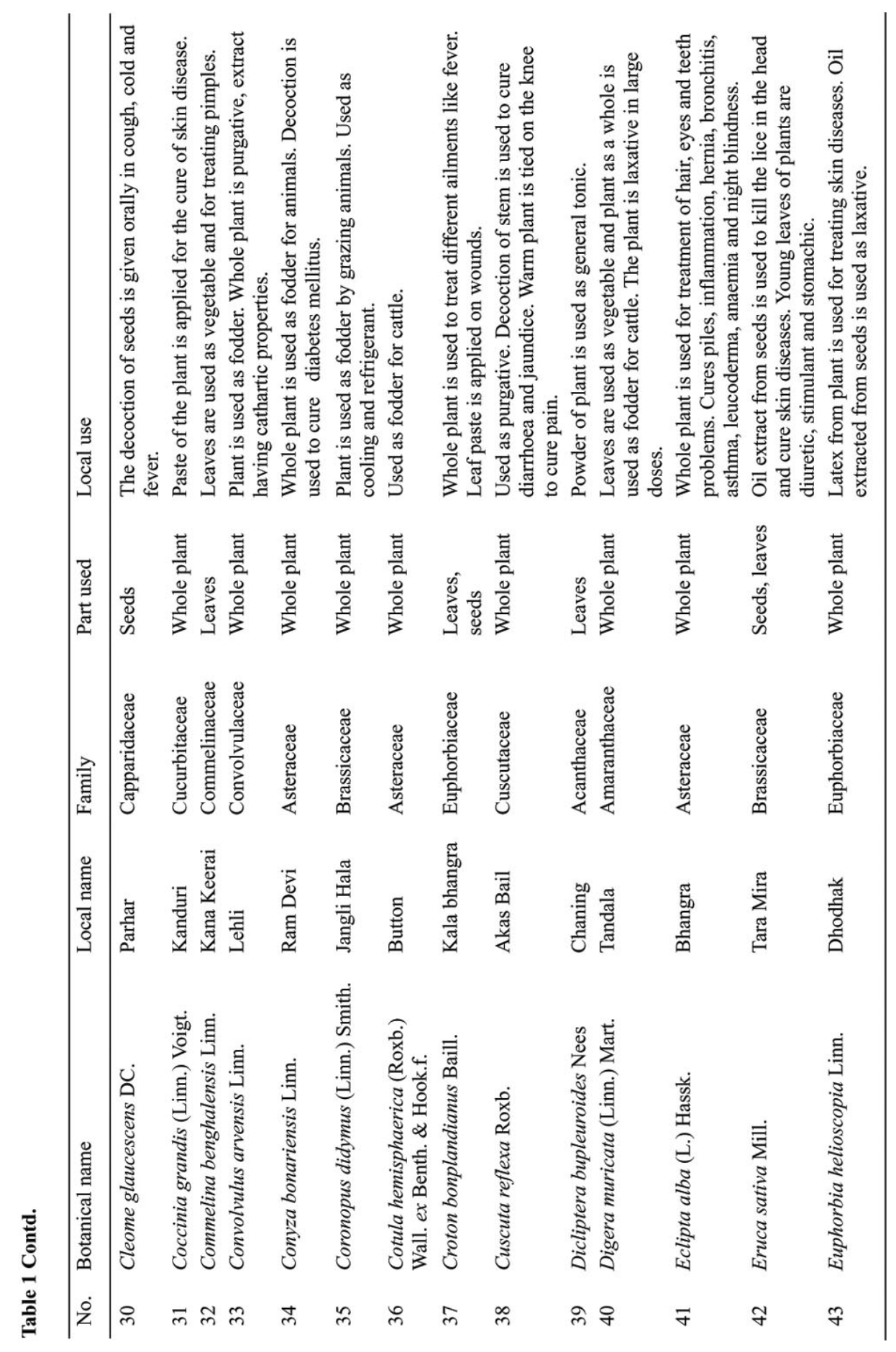




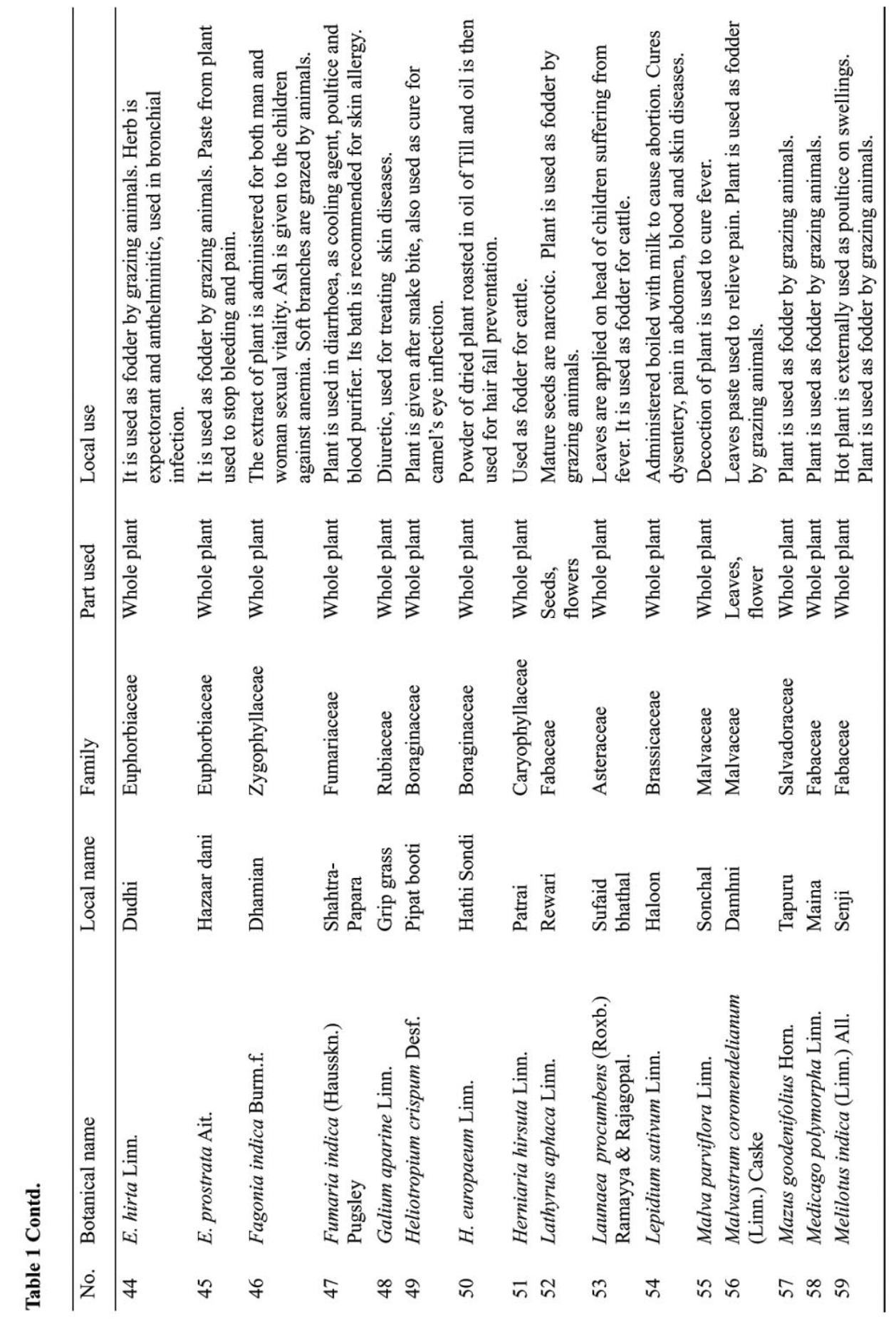




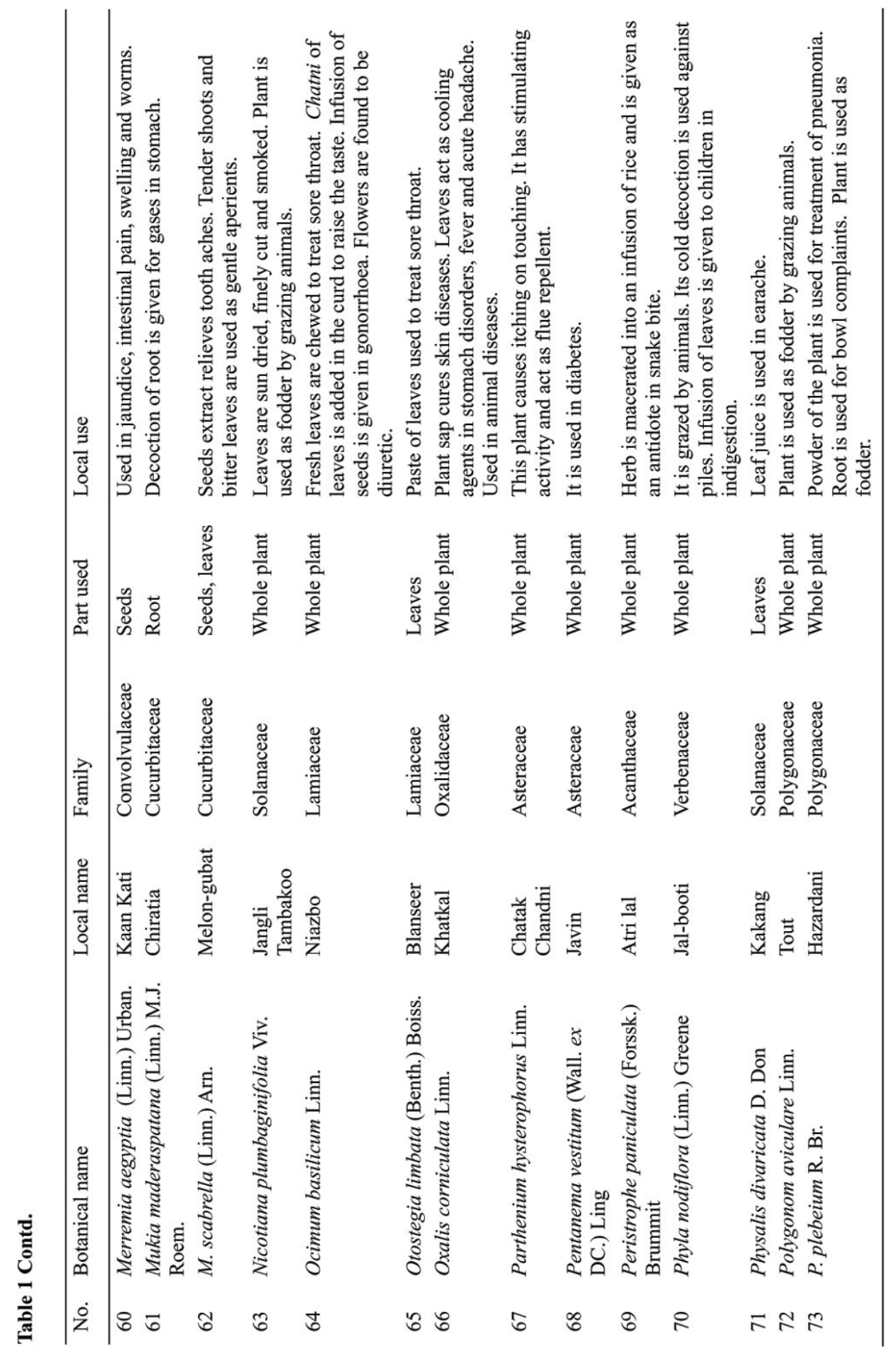




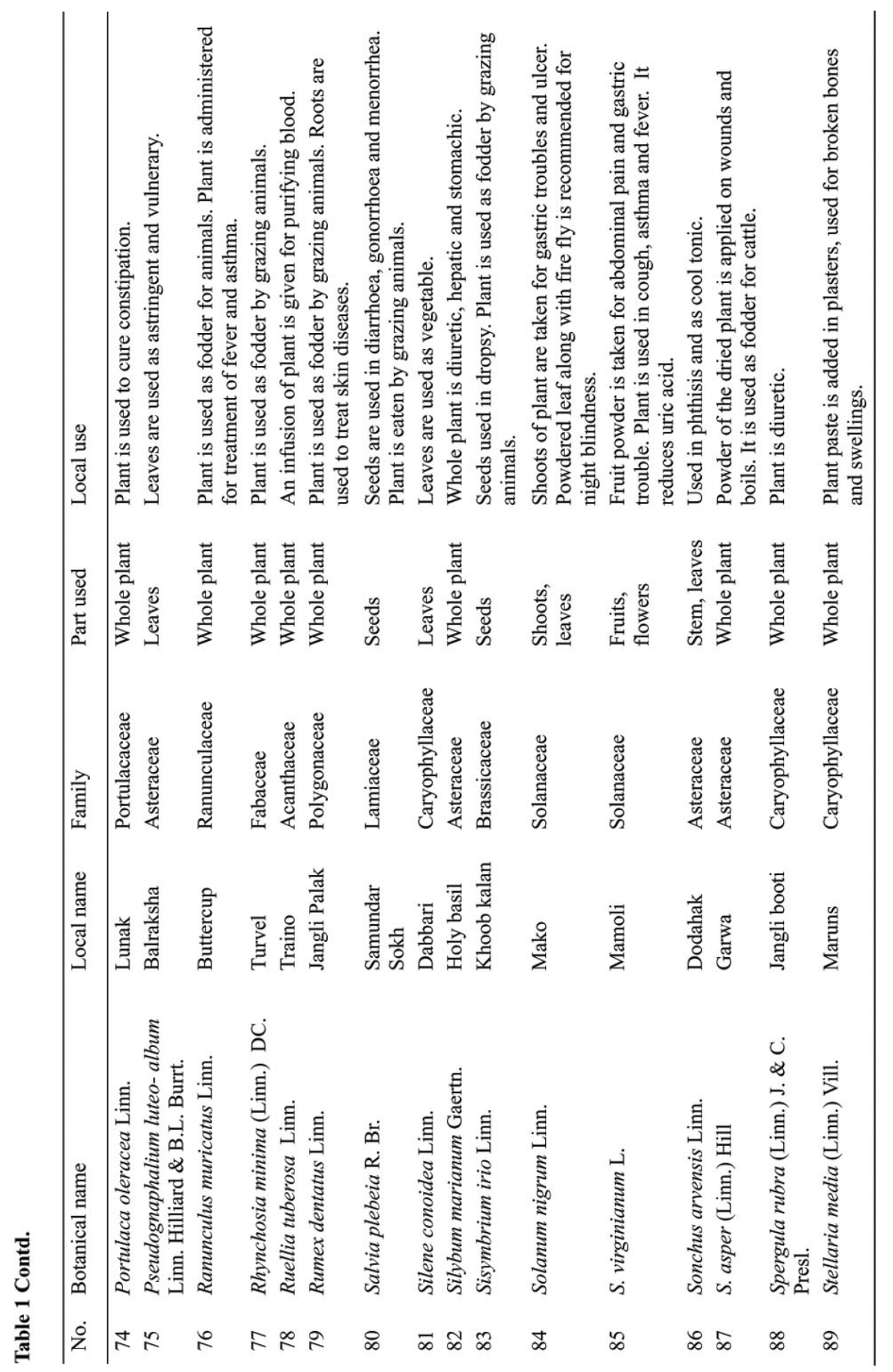




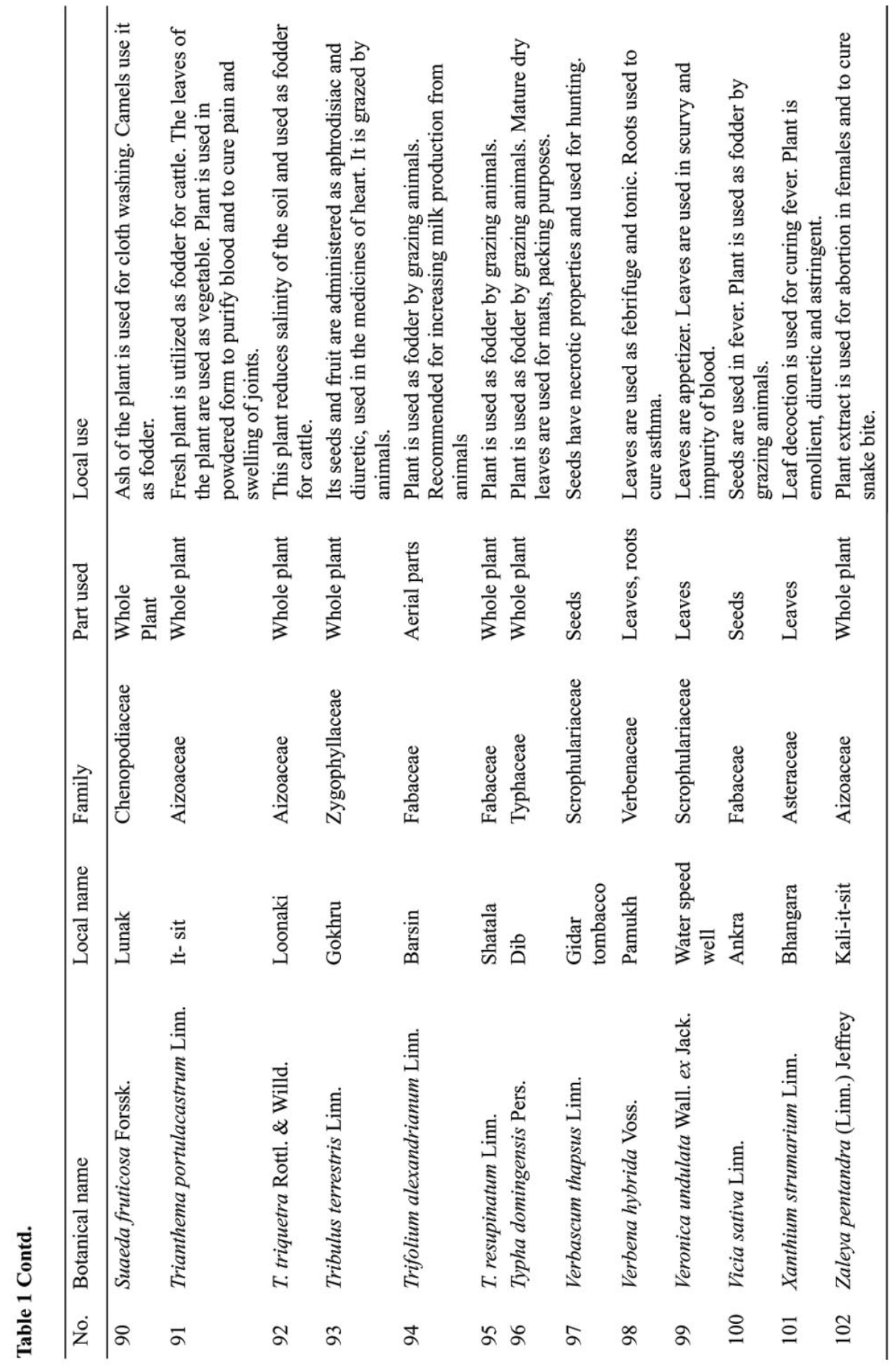




\section{References}

Ali, S.I. and Nasir, Y.J. 1990-92. Flora of Pakistan. Nos. 191-193. Department of Botany, University of Karachi and National Herbarium, PARC, Islamabad.

Ali, S.I. and Qaisar, M. 1992-2007. Flora of Pakistan. Nos. 194-208. Department of Botany, University of Karachi and National Herbarium, PARC, Islamabad.

Cubizolle, H., Tourman, A., Argant, J., Porteret, J., Oberlin, C. and Serieyssol, K. 2003. Origin of European Biodiversity: Palaeo-geographic signification of peat inception during the holocene in the Granitic Eastern Massif Central (France). Landscape Ecology 7: 211-227.

Gjessing, E., Lygren, E., Berglind, L., Gulbrandsen, R. and Skanne, R. 1984. Effect of highway runoff on lake- water quality. Science of the Total Environment 33: 247-257.

Gracia-Miragaya, J., Castro, S. and Paolini, J. 1981. Lead and Zinc levels and chemical fractionation in roadside soils of Caracas Venezuela. Water, Air and Soil Pollution 15: 285-297.

Hamayaun, M., Khan, M.A. and Hayat, T. 2005. Ethnobotanical profile of Utror and Gabral Valleys, District Swat, Pakistan. www.ethnoleaflets.com/leaflets/swat.htm

Hamid, S., Sabir, A.W., Yamin, M. and Chaudry, T.A. 1996. Medicinal plants of families Salvadoraceae, Sapindaceae and Pedaliaceae of Pakistan. Hamdard Medicus 39(3): 69- 101.

Katewa, S.S., Chaudhary, B.L. and Jain, A. 2004. Folk herbal medicines from tribal areas of Rajasthan, India. J. Ethnopharmacol. 92: 41-46.

Mohiuddin, M., Alam, M.K. and Basak, S.R. 2012. Ethno-medico botanical study among the four indigenous communities of Bandarban, Bangladesh. Bangladesh J. Plant Taxon. 19(1): 45-53.

Nasir, E. and Ali, S.I. 1970-1989. Flora of Pakistan. Nos. 1-190. National Herbarium, PARC, Islamabad and Department of Botany, University of Karachi, Karachi, Pakistan.

Nasir, Y.J. and Rubina, A.R. 1995. Wild flowers of Pakistan. Oxford University Press, Karachi, Pakistan.

Patel, P.K. and Patel, M.K. 2012. Ethnogynaecological uses of plants from Gujarat, India. Bangladesh J. Plant Taxon. 19(1): 93-94.

Pragada, P.M. and Rao, G.M.N. 2012. Ethnoveterinary medicinal practices in tribal regions of Andhra Pradesh, India. Bangladesh J. Plant Taxon. 19(1): 7-16.

Rawat, D.S. and Kharwal, A.D. 2010. Ethnobotanical information on Sapium insigne (Royle) Benth.: A conserved plant of Shivalik Hills, India. Bangladesh J. Plant Taxon. 17(1): 97-99.

Sardar, A.A. and Khan, Z.U. 2009. Ethnomedicinal studies on Plant Resources of Tehsil Shakargrah, District Narowal, Pakistan. Pak. J. Bot. 41(1): 11-18.

Shinwari, M.I. and Khan, M.A. 1998. Ethnobotany of the Margalla Hills, Islamabad, Pakistan, Department of Biological Sciences, Quaid-i-Azam University, Pakistan. 